\title{
Selection of Municipal Wastewater Reuse Technology for Agricultural Water by Using Multi Criteria Analysis (MCA): The Case of Walcheren Wastewater Treatment Plant, The Netherlands
}

\author{
NI NYOMAN NEPI MARLENI ${ }^{1}$, AM MAISARAH $^{2}$, LINDAWATI $^{3}$, LUQMAN SALEH $^{4}$, \\ NURKHAKIM ANDRIANI $^{5}$, RISTIE ERMAWATI ${ }^{6}$, AND NITIS ARUMING FIRDAUS ${ }^{6 *}$ \\ ${ }^{1)}$ Universitas Gadjah Mada, Bulaksumur, Yogyakarta, 55281 Indonesia \\ ${ }^{2)}$ Politeknik Perkapalan Negeri Surabaya, Kampus ITS Sukolilo, Jl. Teknik Kimia, Sukolilo, \\ Surabaya, Jawa Timur 6011, Indonesia \\ ${ }^{3)}$ Politeknik Aceh Selatan, Jl. Merdeka, Komplek Reklamasi Pantai, Tapak Tuan, Pasar, Kabupaten \\ Aceh Selatan, Aceh 23715, Indonesia \\ ${ }^{4)}$ Politeknik Pertanian Negeri Pangkajene dan Kepulauan, Kabupaten Pangkajene Dan Kepulauan, \\ Sulawesi Selatan 90655, Indonesia \\ ${ }^{5)}$ Politeknik Negeri Bandung, Jalan Kampus Polban, Ciwaruga, Parongpong, Kabupaten Bandung \\ Barat, Jawa Barat 40559, Indonesia \\ ${ }^{6)}$ Study Program of Environmental Engineering, Akademi Teknik Tirta Wiyata, Magelang, Indonesia
}

\begin{abstract}
The water demands for agricultural purposes are increasing along with the population growth. Unfortunately, the water source is not sufficiently available nowadays. Furthermore, the quality of available water is more deteriorated due to the contamination from many sources such as households, industrial areas and other activities. Water board Scheldestromen handles 16 wastewater treatment plants located in Province of Zeeland in The Netherlands. The total production of treated effluent water from 16 wastewater treatment plants is 50 million annually. Quality of the effluent is relatively good, however, some potential risks related to the number of pathogenic microorganism and some trace metals are still there. The treated effluent is mostly discharged to river near to the treatment plant. The high amount of effluent discharge would potentially to be re-used for fulfill the demand for agricultural water. Therefore, this study aimed to evaluate the feasibility of treated effluent from one of Walcheren wastewater treatment plants located in Ritthem, Province of Zeeland. This study used the method of Multi Criteria Analysis (MCA) for looking the best way to re-use the effluent for agricultural purposes. The MCA questionnaire was developed based on the thorough literature review of effluent reuse. There were six criteria that need to be weighted and six scenario alternatives that need to be scored for the MCA questionnaire. The result show that the effluent water contained pathogenic bacteria (E. coli) and some trace metals $(\mathrm{Ni}$ and $\mathrm{Cu})$ more than suggested by FAO standard. Hence the most preferred technology was combination between closed conduits and UV system, with weighted score 0.78 while others had less weighted score compared to the selected one.
\end{abstract}

Key words: Agricultural, MCA, Wastewater

Correspondence Author: Nitis Aruming Firdaus. Study Program of Environmental Engineering, Akademi Teknik Tirta Wiyata, Magelang, Indonesia, Email: nitisaruming@akatirta.ac.id

\section{INTRODUCTION}

The water demands for agricultural purposes are increasing along with the population growth. Future human population by 2050 will reach 3.7 billion and the highest water use is agricultural sector (Wallace, 
2000). Unfortunately, the water source is not sufficiently available nowadays. Global climate change and over withdrawal of surface water and ground water had triggered water crisis worldwide. Global climate change have contributed to the long drought events and increased the extreme precipitation events (Tao, Yokozawa, Hayashi, \& Lin, 2003).

These are the reason of the increasing number of natural disaster. Population growth is a key factor of every water crisis occurred in this world. Furthermore, the quality of available fresh water is more deteriorated due to the contamination from many sources such as households, industrial areas and other activities (Chang, 2008). Therefore, the alternative water source for agriculture is required to overcome the potential problem of water in the future. Agricultural water comprises of water for irrigation, washing and processing.

In Netherlands, the total production of treated effluent water from 16 wastewater treatment plants is 50 million annually The quality of the effluent is relatively good, however, some potential risks related to the number of pathogenic microorganism and some trace metals are still there (Nieuwlands, 2017). The treated effluent is mostly discharged to river near to the treatment plant. Due to this practice, there is possibility of people health threatening particularly those who live near the riverbank and treatment plants. The high amount of effluent discharge would potentially to be re-used to fulfill the demand for agricultural water. However, a study to look at its feasibility as water source for agriculture have to be conducted to get thorough analysis particularly its impact on human, crops, and infrastructure. Therefore, this study aimed to evaluate the feasibility of treated effluent from one of Walcheren

Journal of Wetlands Environmental Management

Vol 8, No 1 (2020) 63 - 76

http://10.20527/jwem.vol 8 No 1.211 wastewater treatment plants located in Ritthem, Province of Zeeland.

Decision making is a crucial process that determines the sustainability of a project and the satisfactory of the stakeholders. The dilemmas in making a decision often encounter conflict of sociopolitical, economic and environmental interests which eventually constitute a complex problem. Therefore, the solution needs a multidimensional approach such as Multi Criteria Analysis (MCA). Multi criteria analysis (MCA) is an approach that assigns several criteria to address different aspects that affecting a project. MCA analysis has been proven to be systematic process to find the best alternative among different offered alternatives which is preferred by the involved stakeholders and most effective tool for solving such multifactor opposing goal problems. These techniques have been classified into a group of methods, which have been improved very much during last 30 years (Carriço, Gonçalves, Covas, Almeida, \& Alegre, 2014).

Multi criteria analysis involves participation of many people, organization and groups of private and state sector which is called as stakeholders. The procedure of MCA is structurally defined below (Hadipour, Rajaee, Hadipour, \& Seidirad, 2016):

a. Determination of the alternative scenarios

b. Determination of evaluation criteria.

c. Assigning the weight and its definition.

d. Distribution of the questionnaire contains MCA scenarios and evaluation criteria.

e. Ranking the alternative scenarios

f. Analysis of the results

g. Selection of the best scenario.

Schematization of the selected scenario

The advantages of using MCA to make a decision compared to informal judgment are (Kalavrouziotis, Filintas, Koukoulakis, \& Hatzopoulos, 2011): 
a. The method of MCA is identified to be an open and explicit method. The objectives and criteria selection made by decision making group can be openly analyzed and it is possible to be changed and developed if those criteria are considered to be not sufficient. The scores and weighs determined in this method are explicit and developed based on the established techniques. If necessary, those scores and techniques could be amended and cross-referenced to other sources on their relative values.

b. Easy for the decision maker since the performance measurement can be subcontracted to experts.

c. As an important means of communication between the decision-making group and the affected and wider community through the developed score and weight.
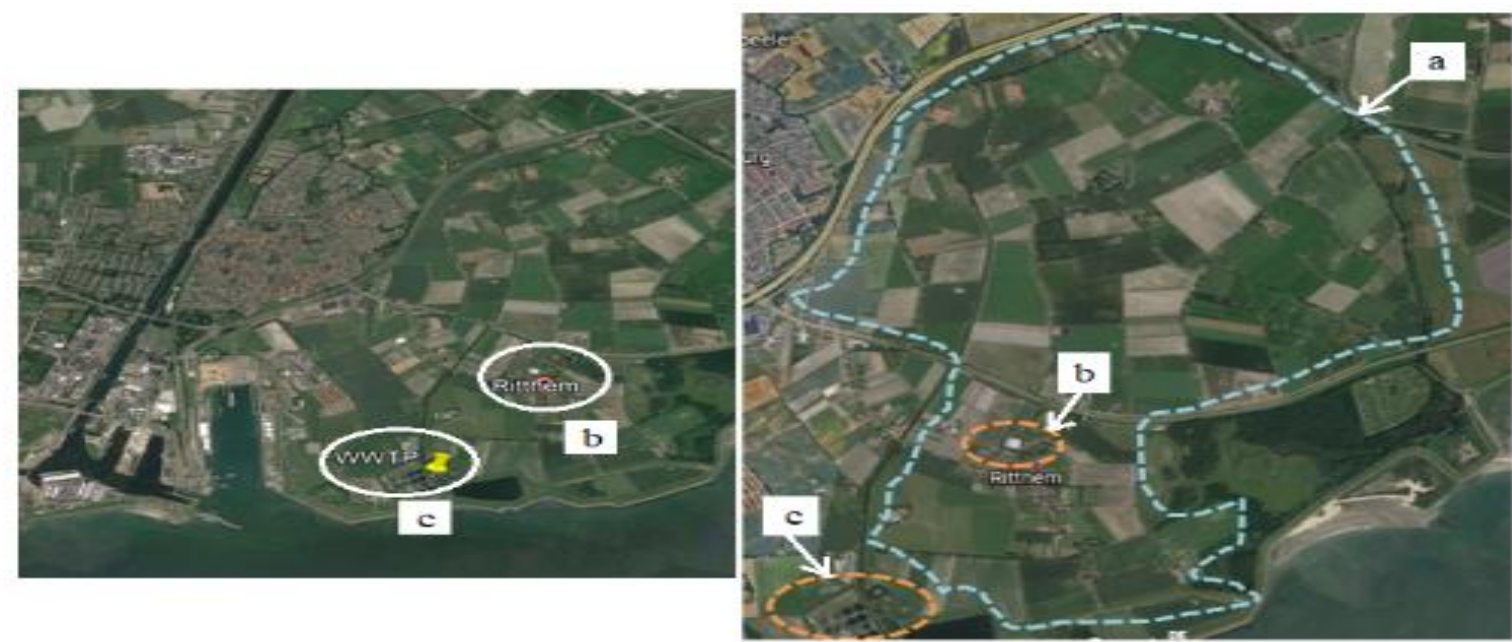

Figure 1. Case study site: (a) Potential Agricultural Area that can be supplied by treated wastewater, (b) Location of Treated Water Storage, and (c) Location of WWTP

Netherlands. Walcheren WWTP built in 1988 and it was expanded in 2003 and 2017. It serves 200,000 p.e. The flowrate in dry weather average is $25,000 \mathrm{~m}^{3} \mathrm{day}^{-1}$ and in wet weather average is $140,000 \mathrm{~m}^{3} \mathrm{day}^{-1}$. The maximum flowrate that has been recorded is $7,800 \mathrm{~m}^{3}$ hour $^{-1}$. There are two separated processes in the WWTP, they are water line Journal of Wetlands Environmental Management Vol 8, No 1 (2020) 63 - 76 http://10.20527/jwem.vol 8 No 1.211
Despite of the advantage offered by MCA, there is also a limitation of MCA in relation with the welfare of the people impacted by a project. The application of MCA does not guarantee that a project adds more to welfare compared to detract (Department for Communities and Local Government, 2009).

\section{METHODS}

\section{Case Study Site}

The Walcheren wastewater treatment plant is in Ritthem, Province of Zeeland, the 


\section{Procedure}

The procedure initiated by analyzing wastewater quality for physical, chemical, microbiological parameter and then compared to the standard of water for agriculture. The historical data of wastewater quality from 1990 to 1997 was also analyzed. From the analysis, the technology setup was created to address the problem identified in the analysis. The evaluation criteria were developed based on the literature study for wastewater reuse.

To assign weights, questionnaires were distributed. For this purpose, experts from Water Board Scheldestromen involved in the process and asked to evaluate the importance of each criteria and their preference on the scenario alternatives.

In the questionnaire distributed to respondent, there were two tables that need to be filled in. The first table was to determine the weight of every criterion for the project of Walcheren WWTP effluent re-uses for agricultural purpose. The second table was evaluation matrix to determine the preference score for every proposed alternative which considers each criterion. In total, there were

six criteria to be assigned weights and there were six alternatives that need to be scored.

\section{Determination of Alternative Scenario}

According to the wastewater quality analysis, it is known that the problematic parameters are the existence of fecal coliform and the high concentration of metal concentration. After conduction test on effluent water aggressivity, the results showed that $\mathrm{pH}$ of effluent tend to be corrosive. Therefore, it was needed to create a set of treatment facility and carrying pipes that were able to handle the problems. Table 1 presents six sets of scenario alternatives to overcome the problem exist in the water.

\section{Determination of Evaluation Criteria}

The evaluation criteria were developed based on the literature review. From literature of wastewater reuse and comparing with the data of effluent quality, there were listed six criteria which include the safety risk, costs, operation and maintenance simplicity, perception issues, required area and treatment efficiency. The justification of selected criteria is described in Table 2. 
Table 1. Alternative Scenarios

No. Alternatives

Coated Closed

1. Conduit - Natural

Process (maturation pond)

Coated Closed

2. Conduit - Natural

Process (constructed wetland)

UV radiation system

3. (in WWTP) - Coated

Closed Conduit

Coated Open channel

4. - Natural Process

(maturation pond)

Coated Open channel

5. - Natural Process

(constructed wetland)

UV system (in

6. WWTP) - Coated

Open channel
The closed conduit is the conduit buried in the ground and usually uses pipes. The coated conduit is necessary to prevent the early deterioration due to internal corrosion caused by transported water

\section{Transmission Line}

Description

\section{Fecal Coliform and Metal} Treatment

1. Maturation pond is a shallow pond which allows the UV from the sun penetrated into the bottom of the pond (Stott \& Tanner, 2005) (Fu \& Wang, 2011).

2. Constructed wetland is treatment systems that use wetland vegetation, soils and their associated microbial assemblages. Reduction of metals and fecal coliforms can be removed in the system (Department Natural Resources Management and Environment, 1992) (Stott \& Tanner, 2005).

3. UV radiation system is physical treatment that has high efficiency in removing the pathogenic bacteria. The UV system is planned to be installed in the Ritthem WWTP. So the effluent from secondary clarifier is radiated by UV before it is sent to agriculture land (Parker \& Darby, 1995) (Müller-Steinhagen \& Branch, 1988).

Coated open channel to prevent the internal corrosion caused by the transported water. There is a chance of metal treatment in the channel because some metals such as $\mathrm{Pb}$ and $\mathrm{Ni}$ flocculate more in the situation of high DO concentration.

\section{Similar to number 1}

Similar to number 2

Similar to number 3 
Table 2. Evaluation Criteria

\begin{tabular}{|c|c|c|}
\hline No. & Criterion & Description \\
\hline 1. & Safety Risks & $\begin{array}{l}\text { Evaluation of both human and environmental risk, } \\
\text { that is, to assess the safety for workers in operating } \\
\text { and maintaining the system as well as the } \\
\text { agricultural worker that use the effluent of the } \\
\text { treated wastewater. The security in case of bad } \\
\text { operations and maintenance or accidents is also } \\
\text { considered in this criterion (Kalavrouziotis, Filintas, } \\
\text { Koukoulakis, \& Hatzopoulos, 2011). }\end{array}$ \\
\hline 2. & Costs & $\begin{array}{l}\text { This criterion contains investment cost to develop a } \\
\text { system as well as operating, maintaining, personnel, } \\
\text { energy and chemical products cost for every } \\
\text { alternative (Carriço, Gonçalves, Covas, Almeida, \& } \\
\text { Alegre, 2014). }\end{array}$ \\
\hline 3. & $\begin{array}{l}\text { Operation \& Maintenance } \\
\text { Simplicity }\end{array}$ & $\begin{array}{l}\text { The selection should take into account the special } \\
\text { needs of system operation and maintenance. If the } \\
\text { operation needs many people to be involved, it can } \\
\text { be a reason for a policy maker to refuse it. The } \\
\text { simplicity of the system could determine the long- } \\
\text { term O \& M success of the system (Hadipour, } \\
\text { Rajaee, Hadipour, \& Seidirad, 2016). }\end{array}$ \\
\hline 4. & Perception Issues & $\begin{array}{l}\text { This criterion is about the view of local population } \\
\text { affected by the system. The perception could be } \\
\text { caused by the aesthetic impact caused by the } \\
\text { presence of the facilities on the landscape, bad } \\
\text { smell which can be produced by the open channel } \\
\text { to irrigate the water as well as the treatment } \\
\text { facilities. As well as the perception of the } \\
\text { population about their health risk due to the } \\
\text { facilities installation (Hadipour, Rajaee, Hadipour, } \\
\text { \& Seidirad, 2016). }\end{array}$ \\
\hline 5. & Area & $\begin{array}{l}\text { The impacted area due to the installation of the } \\
\text { system. The proposed alternatives require a certain } \\
\text { land area to install the system and the barrier area } \\
\text { which might need very wide area. }\end{array}$ \\
\hline 6. & Treatment Efficiency & $\begin{array}{l}\text { Efficiency in reducing pathogenic microorganism } \\
\text { and metal concentration. This criterion considers } \\
\text { the variability of treatment effectiveness under } \\
\text { normal and emergency operation. Evaluation on } \\
\text { this criterion is not only limited to the ability to }\end{array}$ \\
\hline
\end{tabular}




\begin{tabular}{ll} 
No. Criterion & \multicolumn{1}{c}{ Description } \\
\hline & $\begin{array}{l}\text { eliminate pathogens, but also the ability to remove } \\
\text { other undesirable contaminants such as metal. }\end{array}$ \\
\hline
\end{tabular}

In the questionnaire, the criteria were importance. The assigned weight could be in arranged as Table 3 and the respondent was between $0 \%-100 \%$, however, the total asked to weight the criteria based on their percentage from all criteria should be $100 \%$.

Table 3. Weighting Percentage

\begin{tabular}{clll}
\hline No. & \multicolumn{1}{c}{ Criteria } & Weight (\%) \\
\hline 1. & Safety Risks & & \\
2. & Costs & \\
3. & Operation \& Maintenance Simplicity & \\
4. & Perception Issues & \\
5. & Area & \\
6. & Treatment Efficiency & $\mathbf{1 0 0 \%}$ \\
\hline & & TOTAL & \\
\hline
\end{tabular}

Table 4. Score and the level of preference

\begin{tabular}{cll}
\hline Score & \multicolumn{1}{c}{ Definition } & \multicolumn{1}{c}{ Explanation } \\
\hline 5 & Extremely preferred & $\begin{array}{l}\text { A criterion or technique is extremely preferred to } \\
\text { another }\end{array}$ \\
\hline 4 & Strongly preferred & A criterion or technique is strongly preferred to another \\
\hline 3 & Preferred & A criterion or technique is preferred to another \\
\hline 2 & Strongly non-preferred & $\begin{array}{l}\text { A criterion or technique is strongly non-preferred to } \\
\text { another }\end{array}$ \\
\hline 1 & $\begin{array}{l}\text { Extremely non- } \\
\text { preferred }\end{array}$ & $\begin{array}{l}\text { A criterion or technique is extremely non-preferred to } \\
\text { another }\end{array}$ \\
\hline
\end{tabular}

\section{MCA Evaluation Matrix}

The evaluation matrix is intended to score the scenario based on six criteria. There were five score which represents the preference of the technology based on the certain criteria. The score ranged from one to five with the explanation lists in Table 4.
In the questionnaire, the MCA evaluation matrix was arranged as Table 5. Every alternative was judged by each criterion with score 1 to 5 . The assigned score was weighted based on the weight in Table 3 . The total score was the summation of every technology 
Table 5. MCA Evaluation Matrix

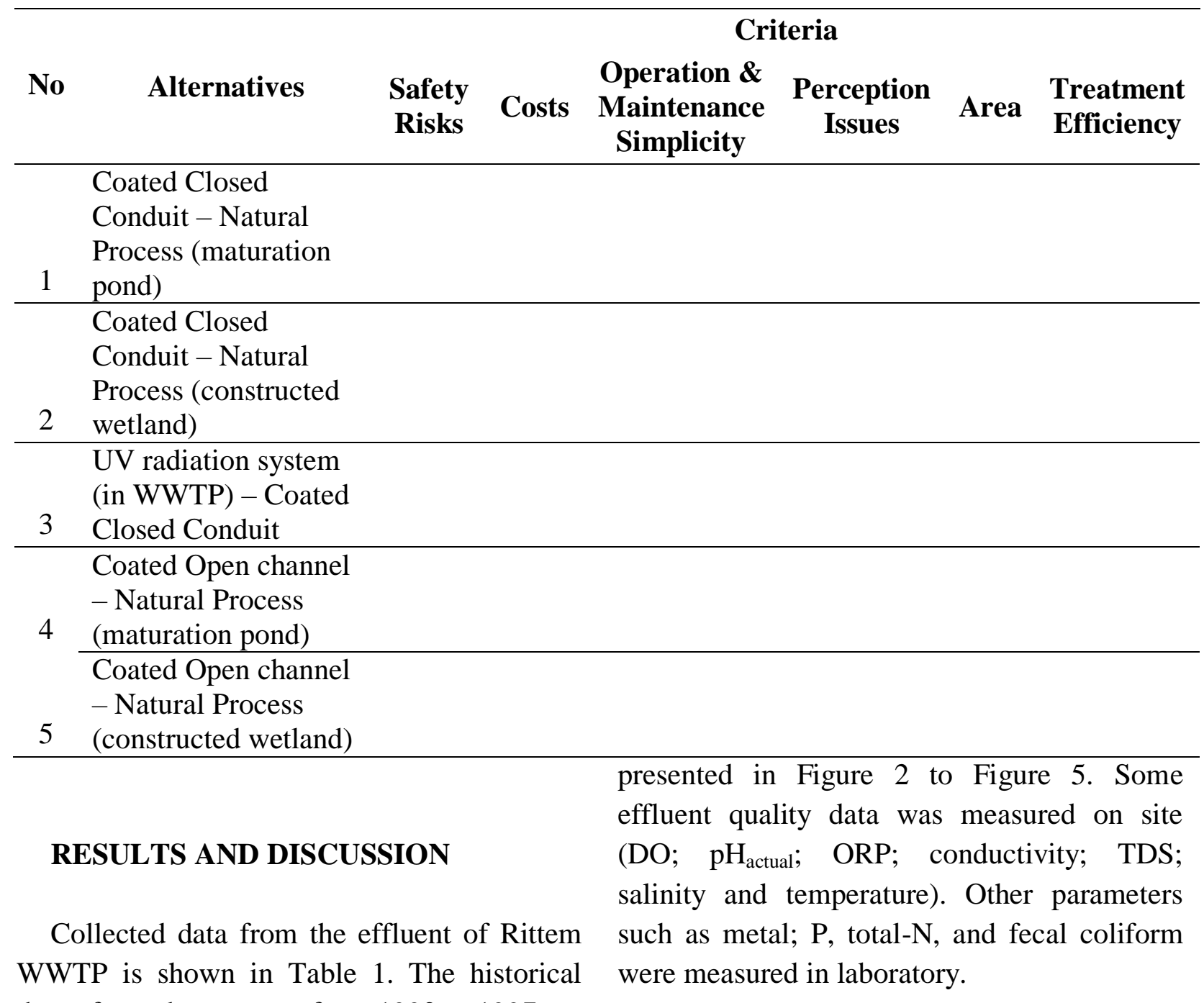
data of metal parameter from 1990 to 1997 are

Table 6. Measurement Quality Data from the Effluent of Ritthem WWTP

\begin{tabular}{lllll}
\hline Parameters* & Concentration & Standard** & Interpretation & $\begin{array}{c}\text { Effect to } \\
\text { Pipe/Human/Crops }\end{array}$ \\
\hline $\mathrm{DO}$ & $5.01 \mathrm{mg} / \mathrm{L}$ & & \\
\hline $\mathrm{pH}_{\text {actual }}$ & 7.02 & $6.5-8.4$ & $\begin{array}{l}\mathrm{pHa}<\mathrm{pHs} \text {, water } \\
\text { tends to be corrosive } \\
\text { to pipe/infrastructure }\end{array}$ \\
\hline $\mathrm{pH}_{\text {saturated }}$ & 7.39 & & \\
\hline ORP & $250.4 \mathrm{mV}$ & & $\begin{array}{l}\text { There is a possibility } \\
\text { to increase in summer }\end{array}$ \\
\hline Conductivity & $2,191 \mu \mathrm{S} \mathrm{cm}^{-1}$ & $\begin{array}{l}0-3,000 \mu \mathrm{S} \\
\mathrm{cm}^{-1}\end{array}$ & $\begin{array}{l}0-2,000 \\
\mathrm{mg} / \mathrm{L}\end{array}$ \\
\hline TDS & $1,092 \mathrm{mg} \mathrm{L}^{-1}$ & & \\
\hline
\end{tabular}




\begin{tabular}{|c|c|c|c|c|}
\hline Parameters* & Concentration & Standard ${ }^{* *}$ & Interpretation & $\begin{array}{c}\text { Effect to } \\
\text { Pipe/Human/Crops }\end{array}$ \\
\hline Salinity & 1.11 PSU & & & \\
\hline Temperature & $14.98^{\circ} \mathrm{C}$ & & & \\
\hline $\mathrm{Ni}$ & $0.227 \mathrm{mg} / \mathrm{L}$ & $\begin{array}{l}\text { Max. } 0.2 \\
\mathrm{mg} / \mathrm{L}\end{array}$ & & $\begin{array}{l}\text { Toxic number } 0.5- \\
1, \text { reduced toxicity at } \\
\text { neutral or alkaline } \mathrm{pH}\end{array}$ \\
\hline $\mathrm{Zn}$ & $<0.2 \mathrm{mg} / \mathrm{L}$ & Max. $2 \mathrm{mg} / \mathrm{L}$ & & $\begin{array}{l}\text { Many variations wide } \\
\text { range plant, reduced } \\
\text { toxicity at } \mathrm{pH}>6\end{array}$ \\
\hline $\mathrm{Cu}$ & $0.126 \mathrm{mg} / \mathrm{L}$ & $0.1-1 \mathrm{mg} / \mathrm{L}$ & & Toxic at $0.1-1$ \\
\hline $\mathrm{Pb}$ & $<0.1 \mathrm{mg} / \mathrm{L}$ & $5 \mathrm{mg} / \mathrm{L}$ & & $\begin{array}{l}\text { Inhibits plants cell } \\
\text { growth }\end{array}$ \\
\hline $\mathrm{PO}_{4}{ }^{3-}$ & $0.236 \mathrm{mg} / \mathrm{L}$ & $0-2 \mathrm{mg} / \mathrm{L}$ & & \\
\hline Total N & $5.53 \mathrm{mg} / \mathrm{L}$ & $20 \mathrm{mg} / \mathrm{L}$ & & \\
\hline Fecal Coliform & $\begin{array}{l}\text { 5,896 CFU/100 } \\
\mathrm{ml}\end{array}$ & $\begin{array}{l}<1000 \mathrm{CFU} \\
100 \mathrm{~mL}^{-1}\end{array}$ & & $\begin{array}{l}\text { Endanger human } \\
\text { health (diarrhea, skin } \\
\text { infection) }\end{array}$ \\
\hline
\end{tabular}

Note: *parameters are sampled in winter, **Source: (Ayers \& Westcot, 1994)

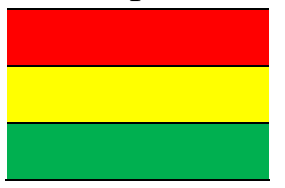

: Exceed the standard/dangerous level

: Warning

: Permitted

Comparison with FAO standard shows some of the parameter such as nickel, copper and fecal coliform exceeded allowed concentration for agriculture water according to FAO which is shown in red color. $\mathrm{pH}$ for the effluent was in range FAO standard however after testing the saturated $\mathrm{pH}$ then the comparison between actual $\mathrm{pH}$ and saturated $\mathrm{pH}$ shows that the effluent water tended to be corrosive to pipes or any other metal infrastructure. The conductivity and the total dissolved solids are in the range of FAO standard; however, the concentration is in upper range. Therefore, there would be possibility of increasing concentration in summertime since those results presented on the table was taken during winter.

The results of the historical data analysis are presented in Figure 2 to Figure 5. In those figures, the red and green line was added to show the standard of FAO (red line) and the recent field measurements (green line). 


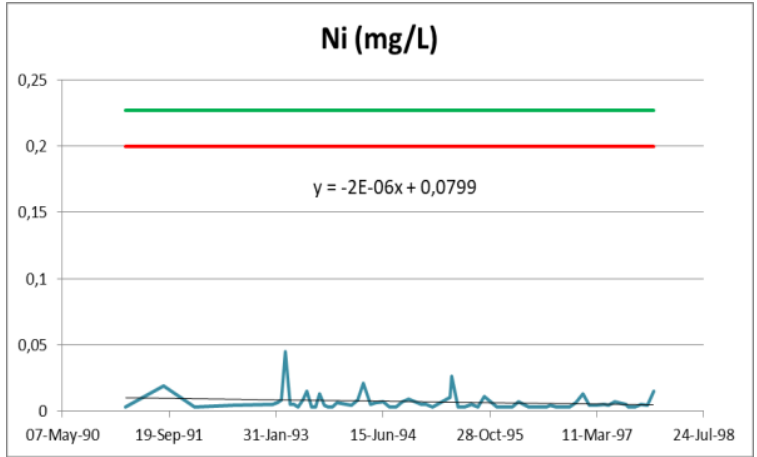

Figure 2. Historical data of $\mathrm{Ni}$

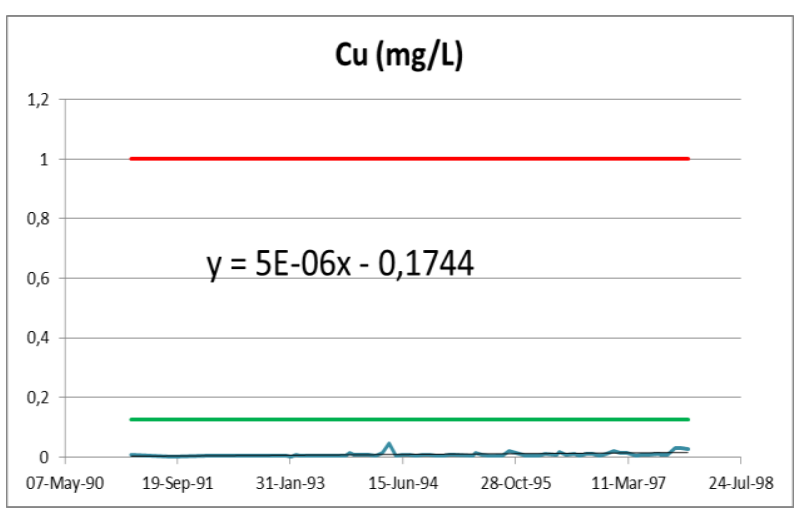

Figure 4. Historical data of $\mathrm{Cu}$

The analysis results show that metal concentration of Nickel (Ni) was far below the current measurement and the standard. It means that the Nickel concentration increases for 10 years duration. The other current metal concentration of $\mathrm{Pb}, \mathrm{Cu}$ and $\mathrm{Zn}$ are quite close to the concentration that was measured 10 years ago, however all those parameters concentration in current measurement is higher than the historical data. The standard of FAO

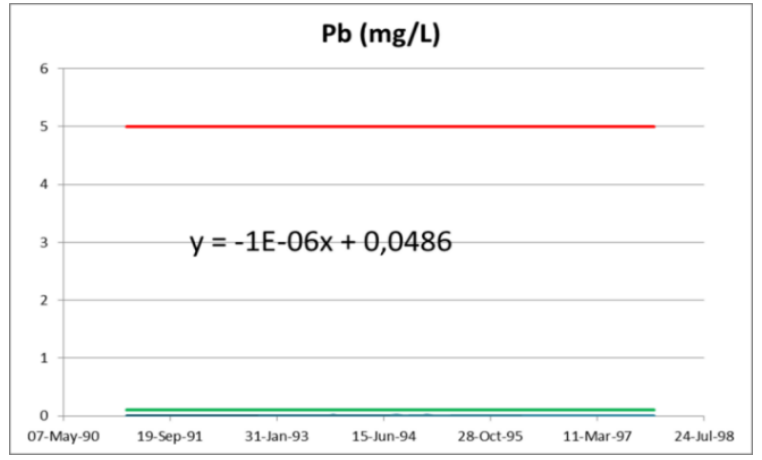

Figure 3. Historical data of $\mathrm{Pb}$

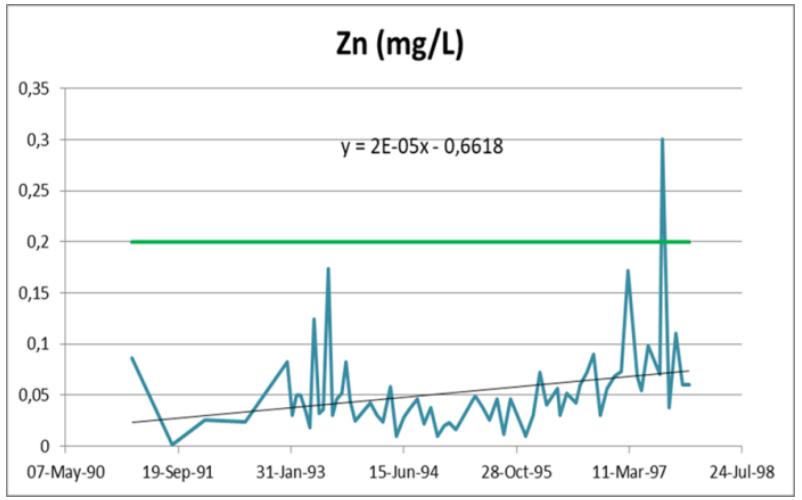

Figure 5. Historical data of $\mathrm{Zn}$

was higher up far from the measurement concentration.

The criteria weights assigned by the stakeholders are presented in Table 7. The scoring of scenario alternatives is presented in Table 8 while the calculated weights of criteria considering all the scenario alternatives is presented in Table 9.

Table 7. Criteria Weighting

\begin{tabular}{|c|c|c|}
\hline No. & Criteria & Weight (\%) \\
\hline 1. & Safety Risks & 10 \\
\hline 2. & Costs & 30 \\
\hline 3. & Operation \& Maintenance Simplicity & 10 \\
\hline 4. & Perception Issues & 10 \\
\hline 5. & Area & 10 \\
\hline 6. & Treatment Efficiency & 30 \\
\hline
\end{tabular}


Table 8. Scenario Alternative Scoring

\begin{tabular}{|c|c|c|c|c|c|c|}
\hline \multirow[b]{2}{*}{ Alternatives } & \multicolumn{6}{|c|}{ Criteria } \\
\hline & $\begin{array}{r}\text { Safety } \\
\text { Risks } \\
\text { (1) }\end{array}$ & $\begin{array}{l}\text { Costs } \\
\text { (2) }\end{array}$ & $\begin{array}{c}\text { Operation \& } \\
\text { Maintenance } \\
\text { Simplicity } \\
\text { (3) }\end{array}$ & $\begin{array}{l}\text { Perception } \\
\text { Issues } \\
\text { (4) }\end{array}$ & $\begin{array}{l}\text { Area } \\
\text { (5) }\end{array}$ & $\begin{array}{c}\text { Treatment } \\
\text { Efficiency } \\
\text { (6) }\end{array}$ \\
\hline $\begin{array}{l}\text { Coated Closed } \\
\text { Conduit - Natural } \\
\text { Process (maturation } \\
\text { pond) }\end{array}$ & 3 & 2 & 3 & 3 & 1 & 3 \\
\hline $\begin{array}{l}\text { Coated Closed } \\
\text { Conduit - Natural } \\
\text { Process (constructed } \\
\text { wetland) }\end{array}$ & 3 & 2 & 3 & 3 & 1 & 3 \\
\hline $\begin{array}{l}\text { UV radiation system } \\
\text { (in WWTP) - Coated } \\
\text { Closed Conduit }\end{array}$ & 4 & 3 & 4 & 4 & 3 & 5 \\
\hline $\begin{array}{l}\text { Coated Open channel } \\
\text { - Natural Process } \\
\text { (maturation pond) }\end{array}$ & 3 & 2 & 3 & 2 & 2 & 3 \\
\hline $\begin{array}{l}\text { Coated Open channel } \\
\text { - Natural Process } \\
\text { (constructed wetland) }\end{array}$ & 3 & 2 & 3 & 2 & 2 & 3 \\
\hline $\begin{array}{l}\text { UV system (in } \\
\text { WWTP) - Coated } \\
\text { Onen channel }\end{array}$ & 2 & 3 & 4 & 3 & 3 & 5 \\
\hline
\end{tabular}

The results showed that the most important criterion is costs and treatment efficiency and the least important is safety risks, $\mathrm{O} \& \mathrm{M}$ simplicity, perception and required area. It must be noted that the one of the most important one is costs which consist of cost of investment; operation and maintenance. Cost component determine the sustainability of the solution because the expensive technology and spare parts could cause problem in long term operation and maintenance. The other most important is treatment efficiency because it is related to the quality of effluent which eventually directly related to human health.
From the questionnaire, the stakeholders have assigned score based on their preference on each criterion. The results are presented in Table 8. The highest score was given to the scenario of using Ultra Violet treatment. From the treatment efficiency, it was considered to be the best option to handle the main problem on the effluent water since Water Board Scheldestromen is very much concern with the issues of pathogenic microbes' presence in the effluent. Closed conduit is also a scenario that receives high scoring in term of safety risk and perception issues since the closed conduit lay 
underground and will not be exposed to the public.

\section{CONCLUSION}

In this study, an MCA has been applied to find the best alternative for wastewater reuse application in the Walcheren WWTP, The Netherlands. The MCA matrix built in this study was distributed to the stakeholders and all aspect related to wastewater reuse from WWTP's effluent was judged for every scenario offered in this study. The matrix built based on the wastewater analysis results and literature study of wastewater reuse. It was found from the study that the best alternative for wastewater reuse is UV radiation system combined with closed conduit for transporting the treated water to agricultural land. Total score for this alternative is 0.78 which is the highest compared to other scenarios. Results from this study can be useful for policy makers and decision-makers in water resource management in Water Board Scheldestromen to make better decisions to reuse the treated wastewater.

Final weights and ranking of alternatives are shown in Table 9. Results of MCA matrix was obtained by weight calculation with the formula below :

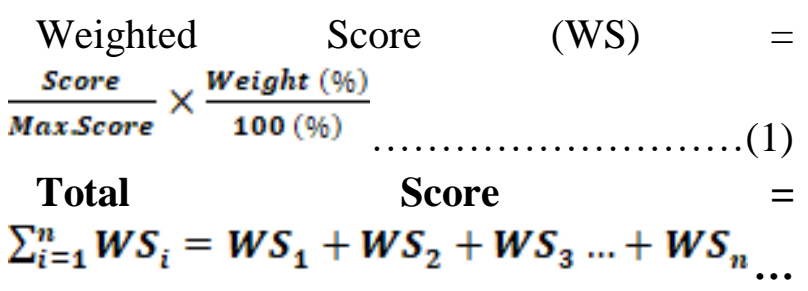

From the calculation and listed in Table 9, the UV radiation method combined with closed conduit has the highest total score that is 0.78 . The UV radiation system and closed conduit was the best alternative to overcome the problem of pathogenic bacteria and minimizing the risk of safety, and health issues according to Water Board Scheldestromen. Therefore, the treatment and transportation scheme will be based on the selected technology as can be seen in Figure 6 .

\section{ACKNOLEDGEMENT}

The authors would like to express their gratitude to the Ministry of Research, Technology, and Higher Education of Indonesia Republic which have provided funding for this research through the Program of Retooling of Vocational Higher Education Lecture. 
Table 9. Final Weight and Rankings of Alternative

\begin{tabular}{|c|c|c|c|c|c|c|c|c|c|c|c|c|c|}
\hline \multirow[b]{3}{*}{ Alternatives } & \multirow{2}{*}{\multicolumn{6}{|c|}{ Criteria }} & \multirow{2}{*}{\multicolumn{6}{|c|}{ Weighted Score }} & \multirow[b]{3}{*}{$\begin{array}{l}\text { Total } \\
\text { Score }\end{array}$} \\
\hline & & & & & & & & & & & & & \\
\hline & $\begin{array}{c}\text { Safety } \\
\text { Risks }\end{array}$ & Costs & $\begin{array}{c}\text { O \& M } \\
\text { Simpli } \\
\text { city }\end{array}$ & $\begin{array}{l}\text { Perception } \\
\text { Issues }\end{array}$ & Area & $\begin{array}{l}\text { Treatment } \\
\text { Efficiency }\end{array}$ & $\begin{array}{c}\text { Safety } \\
\text { Risks }\end{array}$ & Costs & $\begin{array}{c}\text { O \& M } \\
\text { Simpli } \\
\text { city }\end{array}$ & $\begin{array}{l}\text { Perception } \\
\text { Issues }\end{array}$ & Area & $\begin{array}{l}\text { Treatment } \\
\text { Efficiency }\end{array}$ & \\
\hline $\begin{array}{l}\text { Coated Closed } \\
\text { Conduit - Natural } \\
\text { Process (maturation } \\
\text { pond) }\end{array}$ & 3 & 2 & 3 & 3 & 1 & 3 & 0.06 & 0.12 & 0.06 & 0.06 & 0.02 & 0.18 & 0.5 \\
\hline $\begin{array}{l}\text { Coated Closed } \\
\text { Conduit - Natural } \\
\text { Process (constructed } \\
\text { wetland) }\end{array}$ & 3 & 2 & 3 & 3 & 1 & 3 & 0.06 & 0.12 & 0.06 & 0.06 & 0.02 & 0.18 & 0.5 \\
\hline $\begin{array}{l}\text { UV radiation } \\
\text { system (in WWTP) } \\
\text { - Coated Closed } \\
\text { Conduit }\end{array}$ & 4 & 3 & 4 & 4 & 3 & 5 & 0.08 & 0.18 & 0.08 & 0.08 & 0.06 & 0.3 & 0.78 \\
\hline $\begin{array}{l}\text { Coated Open channel } \\
\text { - Natural Process } \\
\text { (maturation pond) }\end{array}$ & 3 & 2 & 3 & 2 & 2 & 3 & 0.06 & 0.12 & 0.06 & 0.04 & 0.04 & 0.18 & 0.5 \\
\hline $\begin{array}{l}\text { Coated Open channel } \\
\text { - Natural Process } \\
\text { (constructed wetland) }\end{array}$ & 3 & 2 & 3 & 2 & 2 & 3 & 0.06 & 0.12 & 0.06 & 0.04 & 0.04 & 0.18 & 0.5 \\
\hline $\begin{array}{l}\text { UV system (in } \\
\text { WWTP) - Coated } \\
\text { Open channel }\end{array}$ & 2 & 3 & 4 & 3 & 3 & 5 & 0.04 & 0.18 & 0.08 & 0.06 & 0.06 & 0.3 & 0.72 \\
\hline Weight & 10 & 30 & 10 & 10 & 10 & 30 & & & & & & & \\
\hline
\end{tabular}

Journal of Wetlands Environmental Management 


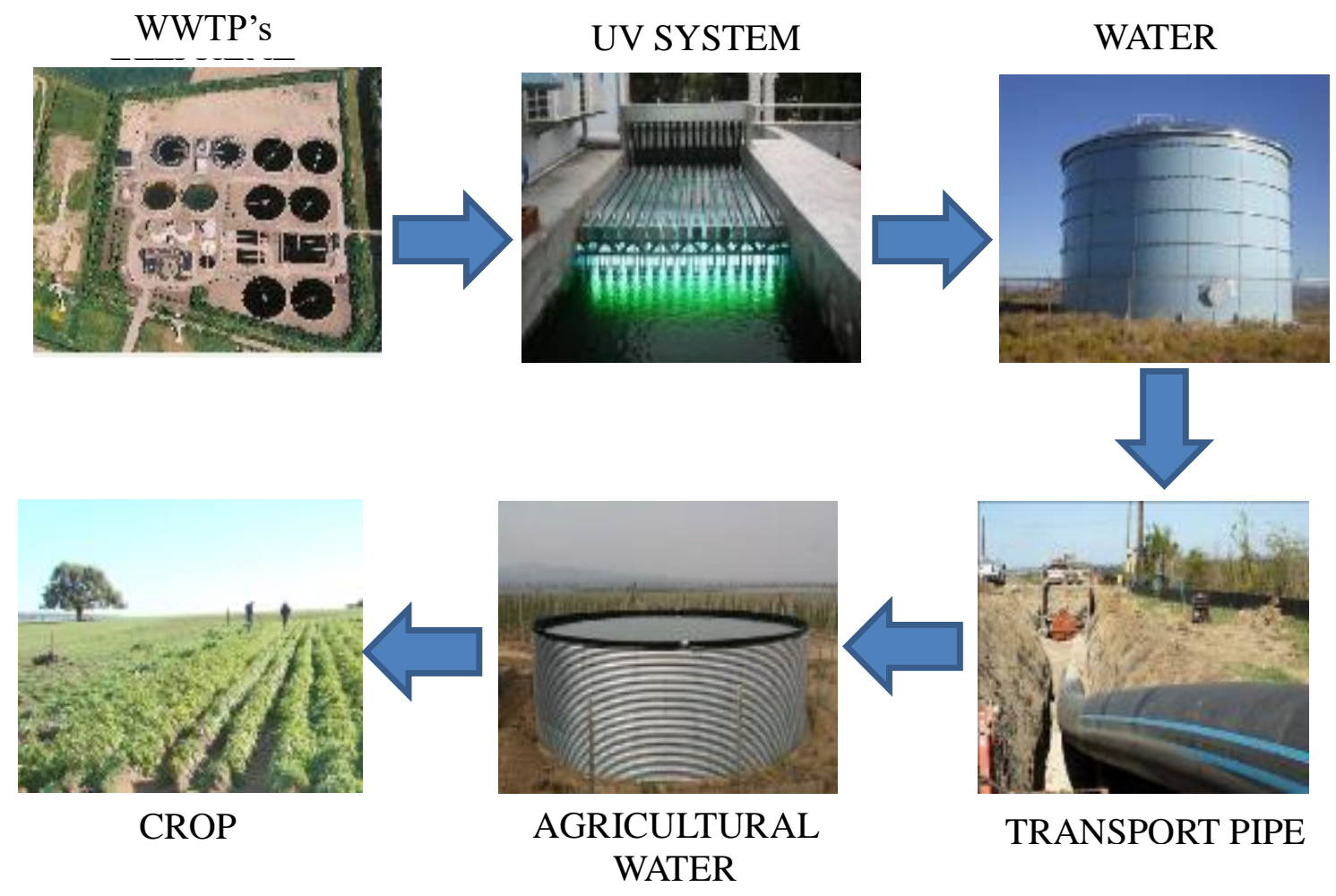

Figure 6. Treatment and Transportation Scheme

\section{REFERENCES}

Ayers, R., \& Westcot, D. 1994. Water quality for agriculture (1 ed.). Rome: FAO.

Carriço, N., Gonçalves, F. V., Covas, D., Almeida, M. d., \& Alegre, H. 2014. Multi-criteria analysis for the selection of the best energy efficient. Procedia Engineering, 70, 292-301.

Chang, H. 2008. Spatial analysis of water quality trends in the Han River basin, South Korea. Water Research, 42(13), 3285-3304.

Department, N. R. 1992. Wastewater treatment. In FAO, Wastewater Treatment and use in agriculture - FAO irrigation and drainage paper 47. Rome: FAO.

Fu, F., \& Wang, Q. 2011. Removal of heavy metal ions from wastewaters : A review. Journal of Environmental Management, 92(3), 407-418.

Journal of Wetlands Environmental Management Vol 8, No 1 (2020) 63 - 76

http://10.20527/jwem.vol 8 No 1.211
Hadipour, A., Rajaee, T., Hadipour, V., \& Seidirad, S. 2016. Multi-criteria decisionmaking model for waastewater reuse application: a case study from Iran. Desalination and Water Treatment, 57(30), 13857-13864.

Kalavrouziotis, I. K., Filintas, A. T., Koukoulakis, P. H., \& Hatzopoulos, J. N. 2011. Application of multicriteria analysis in the management and planning of treated municipal wastewater and sludge reuse in agriculture and land development : The case of Spati's wastewater treatment plant, Greece. Fresenius Environmental Bulletin, 20(2), 287-295.

London, D. f. 2009. Multi criteria analysis : a manual (Vol. 1). London: Department for Communities and Local Government : London.

Müller-Steinhagen, H., \& Branch, C. 1988. Comparison of indices for the scaling and corrosiontendency of water. The canadian 
Journal of chemical Engineering, 66(6), 1005-1007.

Nieuwlands, J. 2017. Effluent Reuse. Vlissingen, Zeeland, Netherlands: Water Board Scheldestromen.

Parker, J., \& Darby, J. 1995. Particleassociated coliform in secondary effluents: shielding from ultraviolet light disinfection. Water Environment Research, 67(7), 1065-1075.

Scheldestromen, W. B. 2017. Walcheren wastewater treatment plant. Ritthem, Zeeland, Netherlands: Water Board Scheldestromen.

Stott, R., \& Tanner, C. 2005. Influence of biofilm on removal of surrogate faecal microbes in a constructed wetland and maturation pond. Water Science \& Technology, 51(9), 315-322.

Tao, F., Yokozawa, M., Hayashi, Y., \& Lin, E. 2003. Future climate change, the agricultural water cycle, and agricultural production in China. Agriculture, Ecosystem \& Environment, 95(1), 203215.

Wallace, J. 2000. Increasing agricultural water use efficiency to meet future food production. Agriculture, Ecosystem \& Environment, 82(1 - 3), 105-119. 